\title{
DARI KAMPUS KE JALANAN: SUATU TINJAUAN ATAS GERAKAN MAHASISWA DI MALAYSIA
}

\author{
Oleh: Mohammad Maiwan*
}

\begin{abstract}
Actually student movement in Malaysia have owned lenght history. Their movement have close related to development of politics. In the past, student movement emerge as part of the struggle to claim independence. But after independence, actively student activism emerge to response some various issues, about domestic or international problems. Their movement was beside pushed by idealism attitude and awareness of high politics, also influenced by turbulence of world politics. Tops of activism student movement in Malaysia taken place in year-end 1960s until early 1970s. Thereafter student movement lost ground. Existing political system solidy have limited various involvement of student in politics, so that cause they withdraw from various issue and problem outside campus.
\end{abstract}

Key Words: Student, movement, politics.

\section{PENDAHULUAN}

Perkembangan gerakan maha-siswa di Malaysia sesungguhnya berkait rapat dengan lingkungan politik yang berlaku di negara tersebut. Keberadaan mereka selalu dipengaruhi oleh kecenderungan serta garis kebijakan politik yang ditempuh penguasa. Selama ini, kurang lebih hampir 30 tahun terakhir, kita nyaris tidak mendengar adanya gerakan mahasiswa di Malaysia yang bersifat politik dalam skala besar yang mempengaruhi situasi politik. Pembangunan ekonomi Malaysia yang berlangsung pesat dan mengesankan, serta kontrol politik yang ketat nampaknya telah berhasil membendung kecenderungankecenderungan radikal dan politisasi di lingkungan mahasiswa. Melalui berbagai kebijakan yang ditempuhnya, pemerintah secara efektif berusaha mengarahkan agar aktifisme dan partisipasi mahasiswa, mengambil bentuk-bentuk kegiatan yang bersifat murni akademik dan non politis.

Meskipun demikian, bukan berarti bahwa kalangan mahasiswa di negara tersebut tidak memiliki kesadaran politik sama sekali. Kalangan mahasiswa di Malaysia, juga memiliki kesadaran yang sama, sebagaimana rekan-rekan mereka di negara-negara lain yang memiliki sifatsifat kritis terhadap berbagai kebijakan pemerintah. Hanya saja, mereka memiliki keterbatasan-keterbatasan dalam menyalurkan pandangannya. Lebih dari itu, gejolak aktifisme mahasiswa secara tidak langsung, untuk sebagian, juga diredam

\footnotetext{
* Dosen pada Program Studi Pendidikan Pancasila dan Kewarganegaraan, Jurusan Ilmu Sosial Politik Fakultas Ilmu Sosial Universitas Negeri Jakarta
} 
oleh berbagai keberhasilan pembangunan serta "kemudahan-kemudahan pendidikan" yang diberikan negara. Karena itu, dapat dipahami bahwa model gerakan mahasiswa yang bersifat politik bukan menjadi arus utama gerakan mahasiswa. Berdasarkan kenyataan tersebut artikel ini berusaha untuk menjelaskan tentang pasang surut gerakan mahasiswa di Malaysia selama ini, serta faktor-faktor yang mempengaruhinya.

\section{LANDASAN TEORITIK}

Pada umumnya, kajian tentang gerakan mahasiswa merupakan bagian dari kajian gerakan sosial. Hal tersebut merupakan satu objek dari kajian perilaku kolektif (collective behavior), yakni satu cabang atau sub disiplin dalam ilmu sosial yang mengkaji berbagai bentuk tindakan kolektif yang memiliki tingkat perlembagaan rendah. Tindakan kolektif boleh dirumuskan sebagai, satu bentuk tindakan bersama oleh kelompokkelompok tertentu yang bertujuan untuk mencapai tujuan tertentu, yang biasanya muncul karena adanya rasa tidak puas terhadap suatu keadaan, yang muncul secara spontan, tidak teratur dan tidak diikat oleh nilai-nilai yang bersifat formal (Crossley 2002: 3-4).

Suatu tindakan kolektif, boleh dikatakan sebagai gerakan sosial sekiranya menepati ciri-ciri tertentu. Della Porta dan Diani (1999: 16) menyebutkan adanya empat ciri, yaitu: Adanya basis jaringan informal; Adanya solidaritas dan keyakinan-keyakinan tertentu, baik dalam bentuk ideologi ataupun nilai-nilai tertentu yang dibagi bersama, yang menggerakkan mereka; Adanya isu yang dimunculkan; serta terdapat frekwensi tertentu dalam berbagai tindakan protes mereka.

Dalam konteks tulisan ini, gerakan mahasiswa kenyataannya menepati ciri-ciri sebagai gerakan sosial. Hanya saja, meskipun tidak semua ciri-ciri yang melekat dalam gerakan mahasiswa menepati ciri gerakan sosial secara menyeluruh, namun boleh dikatakan, pada umumnya sudahpun masuk ke dalam kategori gerakan sosial. Seorang mantan tokoh mahasiswa Indonesia, yakni Marsilam Simanjuntak, memberikan pengertian yang agak fleksibel kepada gerakan mahasiswa sebagai: “...satu aksi massa yang didahului oleh satu perkumpulan umum yang dihadiri oleh ribuan mahasiswa; demonstrasi mahasiswa yang menggambarkan hati nurani rakyat; yang disokong oleh seluruh lapisan mahasiswa pelajar dalam jiwa dan semangat kesamaan dan persatuan. Harus diselaraskan melalui saluran organisasi mahasiswa; bebas dari vested interest, tidak memiliki tujuan politik (praktikal); tidak dimanfaatkan oleh kepentingankepentingan politik tertentu serta berasaskan kepada keadilan dan kebenaran; 
berisikan seruan moral. Tidak untuk merebut kekuasaan, tidak untuk kepentingan politik praktis (Bulkin 1985: 166).

Berdasarkan definisi di atas gerakan mahasiswa hakikatnya merupakan kekuatan netral, yang merupakan gerakan moral yang memperjuangkan kepentingan masyarakat luas, yang tidak minat untuk lebih jauh terlibat dalam usaha untuk meraih jabatan-jabatan dalam kekuasaan. Gerakan mereka lebih terbatas kepada usaha untuk melakukan koreksi terhadap realitas yang dianggap bertentangan dengan kebenaran-kebenaran umum. Ianya merupakan tindakan peringatan ataupun pembetulan ke atas keadaan yang terjadi.

\section{PERKEMBANGAN AWAL}

Kewujudan golongan mahasiswa di Malaysia dapat ditelusuri jauh sebelum Perang Dunia Kedua, bermula pada awal abad ke 20 ketika pemerintah Inggeris memperkenalkan institusi pendidikan tinggi yang pertama di Tanah Melayu, yakni King Edward VII College of Medicine tahun 1905 dan Raffles College tahun 1929, yang kemudian digabung dengan nama baru menjadi University Malaya tahun 1949. Lembaga pendidikan tersebut semuanya terletak di Singapura (Sang, 2003:61-62). Di samping itu juga terdapat Sultan Idris Training College di Tanjung Malim Perak tahun 1922 yang menjadi tempat pendidikan para calon guru.

Lembaga-lembaga pendidikan tinggi inilah yang pertama kalinya melahirkan lapisan elit intelektual Malaya modern serta tempat berseminya kesadaran dan nasionalisme yang terus membesar. Pada tahun 1938 misalnya, sebagian mahasiswa dari Sultan Idris Training College (SITC) bersama rekan-rekan mereka dari Malay College Kuala Kangsar (MCKK), Serdang Agriculture School (SAS), dan Kuala Lumpur Technical School (KLTS) mempelopori berdirinya organisasi politik radikal KMM (Kesatuan Melayu Muda) yang memperjuangkan kemerdekaan Malaya.

Kesadaran kebangsaan semacam itu juga tumbuh di kalangan mahasiswa Malaya yang belajar di Timur Tengah, khususnya Mesir. Mereka terlibat dalam organisasi yang dibentuk bersama mahasiswa Indonesia pada saat itu, yakni al-Jama'ah al-Chairiyah al-Talabiyya al al-Azhariah al-Jawiyah (1925). Pandangan para mahasiswa ini disuarakan dalam majalah organisasi tersebut yang bernama Seruan Azhar. Beberapa tokoh mahasiswa Malaya yang tergabung dalam organisasi al-Jama'ah al-Chairiyah adalah; Othman Abdullah, Muhammad Idris Marbawi, Abdul Wahab Abdullah, Abu Bakar alAsh'ari dan lain-lain (Roff, 1970). Organisasi ini kemudian berubah namanya 
menjadi Persatuan Pemuda IndonesiaMalaya (Perpindom).

Di tempat lain, bersama mahasiswa Indonesia para mahasiswa Malaya ini juga mendirikan organisasi serupa seperti: Persatuan Talabah Indonesia - Malaya (Pertindom) di Mekkah; Majelis Kebangsaan Indonesia - Malaya (Makindom) di Baghdad; Persatuan Indonesia-Malaya (Persindom) di India (Hassan, 1980:26-27). Keterlibatan mereka dalam berbagai organisasi di atas memberikan pengaruh politik penting dalam perjuangan selanjutnya di Tanah Melayu.

Para tokoh mahasiswa dari keduadua aliran di atas, baik yang ada di dalam negeri maupun luar negeri, sekuler maupun Islam kelak akan mendominasi gerakan kemerdekaan di Semenanjung Malaya dan menjadi pemimpin-pemimpin politik. Mereka termasuk Perdana Menteri Kedua Tun Abdul Razak Hussein, Lee Kuan Yew, Goh Keng Swee, dan Tan Sri Dr Tan Chee Khoon (Kim, 2005:9). Di samping menyuarakan sikap kritis dan ketidaksetujuan terhadap kebijakan pemerintah Inggris para mahasiswa tersebut secara terus menerus berusaha membangkitkan solidaritas di kalangan mereka. Meskipun demikian, aktifisme mahasiswa di kampus pada masa itu belum wujud dalam bentuk penentangan terbuka. Hal tersebut di samping masih sedikitnya jumlah mahasiswa juga karena ketatnya kontrol pemerintah Inggris. Ketegangan yang berlaku antara pihak mahasiswa dan universitas lebih bersifat internal pada ketidakpuasan terhadap peraturanperaturan dan layanan kampus yang mengekang.

Namun keadaan tersebut berubah, sesudah Perang Dunia Kedua yang menunjukkan perkembangan politik yang radikal. Sejalan dengan lahirnya negaranegara baru serta tuntutan kemerdekaan yang semakin meluas, maka kalangan intelektual terdidik, termasuk mahasiswa di Malaya terpengaruh ide-ide tersebut. Tuntutan untuk "pemerintahan sendiri", yang merupakan terjemahan lembut daripada istilah "kemerdekaan" semakin sering digunakan. Hal tersebut berbarengan dengan merebaknya pengaruh ideologiideologi politik sehingga melahirkan berbagai organisasi politik.

Salah satu ideologi politik yang berpengaruh di lingkungan kampus tahun 1950-an tersebut adalah ideologi sosialis. Bahkan para mahasiswa dari aliran ini di University Malaya di Singapore mendirikan Socialist Club yang aktif. Meskipun jumlah mereka sesungguhnya minoriti tetapi sangat vokal dan tidak memperoleh tantangan dari mana-mana organisasi kemahasiswaan (Kim, 2005:11). Pada tahap ini, para mahasiswa menjalin hubungan yang rapat dengan gerakan- 
gerakan anti kolonial, termasuk kalangan jurnalis dan organisasi-organisasi serikat buruh nasionalis. Dengan demikian para mahasiswa di universitas secara aktif terlibat dalam perjuangan kemerdekaan (Karim, 1984:1).

\section{PERKEMBANGAN SESUDAH MERDEKA}

Perkembangan gerakan mahasiswa tetap berlanjut setelah Malaya merdeka tahun 1957 dan kampus Universiti Malaya cabang Kuala Lumpur berdiri tahun 1959, serta mencapai status otonomi penuh terpisah dari kampus induk di Singapura tahun 1962. Pada masa ini, pada tahuntahun awal di kampus Kuala Lumpur, karakter aktifisme mahasiswa berbeda. Fokus perjuangan mahasiswa lebih bertumpu pada isu-isu kampus, terutama yang berkaitan dengan kesejahteraan mahasiswa (Karim, 1984:1). Gerakan mahasiswa pada awal tahun 1960-an tidak begitu menonjol, kecuali sekali-sekali muncul membela kebijakan negara pada jaman konfrontasi antara Indonesia Malaysia (1962-1965). Meskipun demikian, beberapa peristiwa yang berlaku pada masa tersebut memberikan inspirasi mendalam kepada mahasiswa, sehingga mempengaruhi jalan pikiran mereka.

Pada awal tahun 1960-an keadaan politik Asia Tenggara mengalami guncangan stabilitas, yang ditandai dengan bangkitnya kekuatan komunis di Indonesia, Indochina, Myanmar, Vietnam serta terjadinya konfrontasi Indonesia-Malaysia yang baru berakhir tahun 1965 setelah Sukarno jatuh. Pada tataran domestik Malaysia sendiri menghadapi masalah berupa keluarnya Singapura dari federasi 1965 serta adanya ketegangan etnik yang semakin meningkat di kedua negara tersebut, yang kemudian menyebabkan terjadinya kerusuhan etnik di Singapura tahun 1964. Keadaan tersebut disusul dengan Perang Vietnam yang meletus tahun 1965 sehingga mengundang simpati dan protes-protes atau demonstrasi di berbagai universitas di Barat. Ideologi kiri kemudian semakin popular di kalangan mahasiswa, termasuk di Malaysia, sehingga banyak forum-forum politik diadakan di kampus. Demonstrasi kemudian menjadi salah satu cara popular di kalangan mahasiswa dalam menuntut sesuatu (Kim, 2005:12).

Satu-satunya kampus yang ada di Malaysia pada waktu itu, yakni Universiti Malaya, menjadi benteng gerakan mahasiswa. Beberapa organisasi mahasiswa yang menjadi saluran aktivitas yang terdapat di universitas tersebut adalah University of Malaya Students Union (UMSU), yang merupakan organisasi mahasiswa terbesar, yang mewakili semua mahasiswa di Universitas Malaya. Kemudian Persatuan Bahasa Melayu 
Universitas Malaya (PBMUM), Chinese Language Society (CLS), The Tamil Language Society (TLS), Persatuan Mahasiswa Islam Universitas Malaya (PMIUM), serta Socialist Club. Semua organisasi mahasiswa di atas, kecuali yang paling akhir yakni Socialist Club, berafiliasi kepada UMSU (Karim, 1984:2).

Dalam beberapa aspek organisasiorganisasi mahasiswa ini bersatu dan bersaing satu sama lain. PBMUM seringkali bersatu dengan PMIUM dalam merespon isu-isu yang muncul. Kedua organisasi mahasiswa ini memiliki basis anggota yang sama yakni para mahasiswa Melayu. Dengan semakin banyaknya mahasiswa Melayu yang memasuki universitas maka kedudukan dua organisasi mahasiswa ini juga semakin kuat. Kedua organisasi ini bertentangan dengan Socialist Club dan juga UMSU. Meskipun demikian pertentangan tersebut bukanlah semata-mata berunsur etnisitas, tetapi lebih pada sikap politik. Sebab banyak juga mahasiswa Melayu yang menjadi anggota Socialist Club atau menduduki kepemimpinan UMSU.

Tahun 1967 merupakan transisi penting gerakan mahasiswa di Malaysia. Pada saat itu gerakan mahasiswa mulai keluar merespon isu-isu di luar kampus yang menyangkut kehidupan umum, terutama masyarakat pedesaan. Salah satu isu menonjol yang melibatkan mahasiswa adalah isu Teluk Gong di Selangor. Dalam kasus ini mahasiswa yang tergabung dalam UMSU dan PBMUM secara langsung terlibat dalam membela penduduk. Kasus ini bermula dari usaha penduduk miskin yang tidak memiliki tanah berjuang untuk memperoleh hak atas tanah yang telah mereka garap dan telah berdiri bangunan rumah. Pemerintah berkeras menggusur penduduk dan menahan sebagian yang lain (Abu Bakar, 1973:60-64). Mahasiswa kecewa dan memprotes kebijakan tersebut. Insiden ini menjadi salah satu titik awal kesadaran mahasiswa akan problem kemiskinan di pedesaan, yang kelak akan menjadi isu penting dalam perjuangan mereka tahun-tahun berikutnya.

Beberapa isu penting lain yang muncul sesudah itu, yakni tahun 1968 adalah isu tentang kebijakan pendidikan nasional dan bahasa Melayu. Para mahasiswa Melayu yang tergabung dalam PBMUM misalnya, berjuang gigih untuk mendaulatkan bahasa Melayu yang merupakan bahasa nasional, sebagai satunya satunya bahasa pengantar dalam perkuliahan. Isu bahasa ini nantinya juga menjadi bagian dari perjuangan mahasiswa dalam menjatuhkan Tunku Abdul Rahman. Di luar itu, pada tahun yang sama mahasiswa Universitas Malaya terlibat aksi demonstrasi menentang invasi Uni Soviet ke Czechoslovakia. Mereka berdemonstrasi di depan Kedutaan Uni Soviet di Kuala 
Lumpur, mengutuk tindakan tersebut sebagai melanggar kedaulatan negara lain dan menuntut agar Uni Soviet menarik diri dari Czechoslovakia. Aksi ini berakhir setelah polisi bertindak dengan kekerasan membubarkan mahasiswa (Abu Bakar, 1973:70-72). Aksi ini juga merupakan demonstrasi massal pertama mahasiswa di luar kampus. Peristiwa-peristiwa di luar negeri secara nyata telah membawa impak terhadap kesadaran kolektif mahasiswa.

\section{MENINGKATNYA AKTIVISME}

Keterlibatan mahasiswa dalam politik nasional semakin meningkat di tahun 1969 menjelang pemilihan umum. Pada bulan-bulan April dan Mei UMSU melakukan beberapa rapat umum di seluruh negara yang dihadiri ratusan ribu rakyat. Mahasiswa mengeluarkan manifesto penting yang menuntut kebebasan, keadilan, perbaikan status ekonomi rakyat, land reform, serta kebijakan pendidikan. Mereka juga menginginkan rakyat lebih terlibat dalam proses pengambilan keputusan dan politik nasional berdasarkan demokrasi dan keadilan. Tujuan rapat umum tersebut adalah untuk memberikan gambaran yang benar kepada rakyat tentang keadaan politik tanah air (Abu Bakar, 1973:80). Sikap mahasiswa ini merefleksikan keprihatinan terhadap suasana politik sekaligus menunjukkan karakter progresif gerakan mereka. Karena itu pemerintah tidak begitu menyukai aksi-aksi ini.

Namun demikian gerakan mahasiswa terus berlanjut dan bahkan terseret dalam arus "kampanye panas" yang menuntut pengunduran diri Tunku Abdul Rahman selepas peristiwa kerusuhan rasial 13 Mei 1969. Dalam serangkaian demonstrasi di kampus, mahasiswa UMSU yang dipimpin oleh Syed Hamid Ali dan PBMUM oleh Anwar Ibrahim membongkar kebobrokan-kebobrokan pemerintah dan secara tegas mengemukakan kegagalan Tunku. Tanpa ragu-ragu mahasiswa mendesak agar Tunku turun dari jabatannya. Sikap ini ditanggapi pemerintah dengan keras. Pada tanggal 29 Agustus 1969 polisi menyerbu kampus Universitas Malaya dan menahan beberapa orang tokoh mahasiswa. Tindakan ini segera diprotes mahasiswa karena dianggap melanggar otonomi kampus (Karim, 1984:5-6). Secara keseluruhan gerakan mahasiswa tersebut juga telah berperan dalam menekan pemerintah, yang pada akhirnya mengubah haluan pembangunan dengan mengadopsi kebijakan yang lebih pro rakyat, khususnya bumiputera.

Sebagai akibat daripada kerusuhan 13 Mei 1969 pemerintah kemudian menetapkan Akta Universiti dan Kolej Universiti (AUKU) atau Undang-Undang Perguruan Tinggi dan Universitas pada 
tahun 1971. Peraturan ini memberlakukan sejumlah pembatasan-pembatasan terhadap aktivitas mahasiswa (Rahim, 1992:19). Dalam Undang-Undang tersebut para mahasiswa atau organisasi kemahasiswaan dilarang berafiliasi, menyatakan dukungan, bersimpati ataupun beroposisi terhadap partai politik atau mana-mana serikat buruh. Pelanggaran terhadap peraturan ini akan dikenakan denda sebesar RM 1.000 atau hukuman penjara selama enam bulan atau kedua-duanya sekaligus. Melalui Undang-Undang ini pemerintah memberikan wewenang kepada Dewan Universitas untuk melarang atau membubarkan setiap organisasi mahasiswa yang bertindak dengan cara yang dianggap membahayakan atau merugikan keberadaan universitas (Anwar, 1990:28).

Tekanan ini secara jelas akan melemahkan kekuatan mahasiswa. Pemerintah berusaha agar aktivitas mahasiswa dapat dikontrol serta disalurkan dengan baik. Oposisi terbuka para mahasiswa, sebagaimana yang pernah terjadi tahun 1969 yang dikhawatirkan dapat mengguncang stabilitas politik, diharapkan tidak berulang lagi. Meskipun untuk sementara peraturan di atas berjalan cukup efektif, namun harapan pemerintah nampaknya tidak kesampaian. Para mahasiswa belum sepenuhnya dapat menerima pembatasan-pembatasan semacam itu. Hal tersebut di samping sikap keras sebagian mahasiswa, juga karena mahasiswa tahu bahwa Undang-Undang semacam itu akan mengebiri hak-hak dasar mereka.

Karena itu, mahasiswa mengecam pemerintah seraya menyatakan bahwa Undang-Undang tersebut meruntuhkan prinsip-prinsip demokrasi dan kebebasan berpendapat. Penentangan itu juga memperoleh dukungan sebagian partaipartai politik. Beberapa demonstrasi di kampus menentang Undang-Undang tersebut juga dilakukan pada tahun 1971, 1972 dan sekali lagi dalam tahun 1973 (Karim, 1984:7). Keadaan ini menunjukkan tekad mahasiswa untuk terus menerjang pembatasan-pembatasan itu dan memanfaatkan celah-celah kesempatan yang masih ada. Salah satu tantangan terbuka di luar kampus setelah diberlakukannya Undang-Undang tersebut adalah terjadinya demonstrasi besar pada tanggal 14 Juni 1971.

Pada saat itu untuk pertama kalinya mahasiswa Universitas Kebangsaan Malaysia, yang baru didirikan, bersama mahasiswa Universitas Malaya bersatu melakukan demonstrasi besar-besaran, menyambut kedatangan Perdana Menteri Thailand Thanom Kittikachorn di Kuala Lumpur. Mereka memprotes penindasan yang dilakukan pemerintah Thailand terhadap masyarakat Melayu Patani, dan menyuarakan dukungan terhadap 
perjuangan kaum Muslim di sana. Demonstrasi tersebut diorganisir Persatuan Mahasiswa Islam Universiti Malaya. Dalam kejadian tersebut terjadi bentrokan fisik antara mahasiswa dengan pihak polisi yang bertindak brutal sehingga mengakibatkan beberapa mahasiswa lukaluka dan sebagian lagi ditahan (Abu Bakar, 1973:145-149).

Peristiwa yang lain adalah demonstrasi anti-Amerika tanggal 13 Oktober 1973. Para mahasiswa dari Universitas Malaya yang dikoordinir pihak University of Malaya Students Union (UMSU) dan beberapa universitas lain melakukan demonstrasi di depan kantor kedutaan besar Amerika Serikat di Kuala Lumpur. Hampir empat ribu mahasiswa dari berbagai aliran politik bersatu menentang kebijakan Amerika yang mendukung Israel dalam konflik di Timur Tengah. Protes tersebut dilancarkan menyusul terjadinya konflik Arab-Israel 1973. Para mahasiswa mengecam, serta menentang keras sikap berpihak Amerika yang dianggapnya sebagai imperialis dan secara terbuka menyatakan solidaritas terhadap perjuangan bangsa Arab dan Palestina untuk memperoleh hak-haknya (Karim, 1984:9-10).

\section{PUNCAK AKTIVISME}

Momentum gerakan mahasiswa mencapai puncaknya tahun 1974. Dua peristiwa penting yang terjadi pada masa ini adalah insiden Tasik Utara dan Baling. Insiden Tasik Utara Johor yang terjadi bulan September 1974 bermula dari usaha pemerintah untuk menggusur pemukiman liar orang-orang Melayu yang miskin di wilayah tersebut. Meskipun penduduk setempat menentang keras, namun rencana tersebut berjalan terus sehingga menimbulkan ketegangan. Beberapa mahasiswa dari Universitas Malaya turun ke lokasi dan bersama penduduk memprotes sikap sepihak penguasa. Tindakan ini ditanggapi pihak polisi dengan menahan mahasiswa karena dituduh memprovokasi penduduk. Organisasi persatuan mahasiswa dari semua kampus yakni: Universitas Malaya, Universitas Kebangsaan Malaysia, Universitas Teknologi Malaysia, Universitas Sains Malaysia, Universitas Putra Malaysia juga mendukung sikap masyarakat setempat. Akibatnya ribuan mahasiswa melakukan sejumlah demonstrasi termasuk di depan kantor Perdana Menteri. Namun pemerintah tetap berkeras dengan rencana-rencananya untuk menghentikan aksi-aksi yang dianggap liar ini dengan berbagai cara, sehingga terjadi kekerasan antara polisi dan mahasiswa (Karim, 1984:11-13).

$$
\text { Peristiwa Tasik Utara }
$$

sesungguhnya hanya pembuka awal dari gerakan mahasiswa berikutnya yang lebih 
22 JURNAL ILMIAH MIMBAR DEMOKRASI

besar, yakni peristiwa Baling. Insiden di Baling, Kedah terjadi bulan November 1974. Peristiwa tersebut terjadi ketika ribuan petani, yang kebanyakan petani kecil, di wilayah itu melakukan serangkaian protes menuntut pemerintah agar menaikkan harga getah dan mengendalikan harga pangan serta kebutuhan pokok lainnya yang terus meningkat. Hal tersebut terjadi menyusul berlakunya inflasi sejak tahun 1973, yang memukul kehidupan petani dan masyarakat kecil lainnya. Bahkan ada isu bahwa terjadi kelaparan di wilayah Baling. Perjuangan petani tersebut didukung oleh aktifis mahasiswa universitas dan institusiinstitusi pendidikan tinggi di seluruh negara, yang merasa bahwa pemerintah tidak tanggap terhadap penderitaan rakyat. Akibatnya tanggal 3 Desember 1974 ribuan mahasiswa melakukan serangkaian demonstrasi besar-besaran di Kuala Lumpur.

Mereka mendesak pemerintah agar segera menangani inflasi, memperbaiki nasib petani, dan menghukum para pejabat yang korup. Mahasiswa yakin bahwa sebagian akar persoalan di masyarakat adalah mentalitas para pejabat yang buruk dan ingin memperkaya diri sendiri. Namun, pemerintah tidak menggubris tuntutan semacam itu, sehingga polisi dan FRU (Federal Reserve Unit) turun tangan meredakan situasi dengan kekerasan.
Sebagian mahasiswa luka-luka dan seribu lebih ditahan. Tekanan ini tidak mematahkan semangat mahasiswa. Mereka justru melanjutkan aksi pada hari-hari berikutnya di kampus Universitas Malaya, sampai kemudian pihak polisi memasuki kampus pada tanggal 9 Desember 1974. Selanjutnya, beberapa aktifis mahasiswa, dosen, serta pemimpin politik yang bersimpati dan mendukung gerakan tersebut sejak awal ditahan. Beberapa orang di antaranya adalah: Prof. Syed Husin Ali, Anwar Ibrahim, serta para Presiden Persatuan Mahasiswa dari Universitas Malaya, Universitas Sains Malaysia, Universitas Kebangsaan Malaysia, Institut Teknologi MARA (Karim, 1984:15).

Segera sesudah itu, untuk memulihkan situasi, pada tahun 1975 pemerintah mengamandemen Akta Universiti dan Kolej Universiti (AUKU) atau Undang-Undang Perguruan Tinggi dan Universitas 1971 dan menggantinya dengan undang-undang baru yang lebih keras. Pemerintah tidak ingin kecolongan yang kedua kalinya karena gagal mengontrol mahasiswa. Dalam UndangUndang ini dinyatakan bahwa: Semua organisasi mahasiswa yang ada dibubarkan; mahasiswa dilarang memberikan sokongan kepada pihak-pihak di luar kampus; menjadi anggota organisasi-organisasi di luar kampus; 
organisasi persatuan mahasiswa sendiri juga dilarang bergabung dengan manamana organisasi di luar kampus; mahasiswa dilarang menyimpan atau mencari dana kegiatan, semua dana kini diatur pimpinan kampus; semua kegiatan termasuk mengorganisasi forum atau mengundang pembicara dari luar serta setiap anggaran yang akan digunakan harus memperoleh persetujuan tertulis dari Wakil Rektor bidang Kemahasiswaan; juga dilarang berkumpul lebih dari lima orang dan mempublikasikan sebarang dokumen tanpa izin lebih dahulu. Sebagai gantinya pemerintah membentuk Dewan Perwakilan Mahasiswa, yang memiliki kekuasaan dan wewenang sangat terbatas (Rahim, 1992).

Secara keseluruhannya UndangUndang Perguruan Tinggi dan Universitas 1975 ini telah membawa implikasi luar biasa, yang menandai era berakhirnya gerakan mahasiswa sebagai salah satu kekuatan sosial politik penting di Malaysia. Sejak itu, aktivitas politik mahasiswa di seluruh negara nyaris tidak ada. Para mahasiswa takut bahwa keterlibatan mereka dalam aktivitas politik, dan oposisi yang bertentangan dengan kebijakan negara akan membawa resiko yang lebih besar, baik dikeluarkan dari universitas maupun ditamatkan pinjaman beasiswanya. Kebijakan di atas secara tidak langsung telah berhasil mengubah haluan gerakan mahasiswa dari sikap lantang dan radikal kepada sikap yang lebih moderat. "Sudut pidato berkubur dan demonstrasi tidak lagi menjadi buah mulut. Mahasiswa tidak lagi bebas berpolitik seperti dahulu" (Abdullah, 2005:188).

Salah satu aspek penting yang menyumbang kepada peningkatan gerakan mahasiswa pada masa itu adalah berdirinya universitas-universitas baru sejak akhir tahun 1960-an. Beberapa universitas tersebut adalah: ITM (Institut Teknologi Mara) (1967); USM (Universitas Sains Malaysia) (1969); UKM (Universitas Kebangsaan Malaysia (UKM) (1970); UPM (Universitas Pertanian Malaysia) (1971); UTM (Universitas Teknologi Malaysia) (1972). Bertambahnya universitas berarti pula bertambahnya jumlah mahasiswa. Kebanyakan mereka adalah generasi pertama bumiputera Melayu yang memperoleh tempat di universitas. Mereka umumnya berasal dari latar belakang daerah-daerah pedesaan yang miskin, yang memiliki komitmen dan idealisme tinggi, yang melihat adanya kontradiksi dalam realitas kehidupan para pemimpinnya yang jauh dari harapan. Para mahasiswa inilah yang memainkan peran menonjol dalam menggerakkan perubahanperubahan di tahun 1970-an.

Di samping itu, gerakan mahasiswa pada pertengahan 1970-an tersebut, untuk sebagian juga dirangsang oleh adanya "ruang kosong" yang ditinggalkan partai- 
24 JURNAL ILMIAH MIMBAR DEMOKRASI

partai oposisi, terutama PAS (Partai Islam Se Malaysia) dan beberapa partai lainnya seperti PPP (People's Progressive Party) dan Gerakan, karena mereka bergabung dalam koalisi pemerintah Barisan Nasional. Partai-partai oposisi inilah yang semula secara tradisional memainkan peran sebagai watchdog dan pengkritik gigih kebijakan pemerintah.

\section{GERAKAN MAHASISWA PASCA 1975 MENUJU APATISME}

Sesudah tahun 1975 gerakan mahasiswa di Malaysia mengalami transformasi baru. Aktifisme mahasiswa menyaksikan kemerosotan yang sangat tajam. Kalangan mahasiswa yang sebelum itu tampil ke depan menyuarakan aspirasi rakyat secara berangsur-angsur kehilangan semangat dan idealismenya. Slogan bahwa mahasiswa adalah "jurubicara masyarakat" tidak lagi mendapat tempat. Ketatnya peraturan kampus menyebabkan mahasiswa harus menumpukan sepenuhnya perhatian mereka kepada kegiatan-kegiatan yang bersifat akademik. Kelompokkelompok mahasiswa, yang pada masa lalu menonjol, baik yang beraliran sosialis maupun nasionalis telah kehilangan pengaruhnya di kampus.

Menjelang tahun 1980-an dan beberapa tahun sesudahnya kehidupan kampus di Malaysia diwarnai dengan bangkitnya kelompok-kelompok mahasiswa Islam yang menguasai politik kampus. Mereka memiliki afiliasi dengan salah satu kelompok dakwah dan politik seperti: ABIM (Angkatan Belia Islam Malaysia), PAS (Partai Islam Se Malaysia), IRC (Islamic Representative Council) atau Republik Islam, Tabligh, dan Darul Arqam. Akar-akar kecenderungan ini dapat dilacak pada kebangkitan Islam yang dipelopori ABIM di bawah Anwar Ibrahim awal tahun 1970-an serta kembalinya mahasiswa-mahasiswa Malaysia dari luar negeri (Anwar, 1990).

Di luar arus kebangkitan kelompok Islam tersebut, sepanjang tahun 1980-an gerakan mahasiswa juga diwarnai dengan pendirian organisasi-organisasi baru yang berlingkup kecil dan terbatas yang lebih mencerminkan persaingan sengit antara kelompok-kelompok oposisi dan pemerintah. Keberadaannya hanya sesaat dan tidak berumur panjang. Sebagiannya bertahan dan sebagiannya mati. Organisasi-organisasi itu seperti; BBMN (Barisan Bertindak Mahasiswa Negara); GAMIS (Gabungan Mahasiswa Islam Se Malaysia); dan APMN (Angkatan Perpaduan Mahasiswa Negara). Keadaan yang sama berlaku pada era 1990-an yang menyebabkan kekuatan mahasiswa terpecah-pecah karena infiltrasi dan pengaruh partai-partai politik. Beberapa organisasi mahasiswa yang muncul pada masa ini antara lain adalah: AMAN 
(Angkatan Mahasiswa Negara) yang pro pemerintah; BPMN (Badan Perunding Mahasiswa Negara) yang pro oposisi; JBHARUT (Jawatankuasa Bertindak Hak Asasi Rakyat Universiti-Universiti Tempatan) (Ahmad, 2003:6).

Di samping itu sepanjang tahun 1980-an dan 1990-an tersebut muncul pula berbagai kelompok-kelompok mahasiswa tidak resmi yang dapat dianggap sebagai partai politik mahasiswa di kampus, namun kedudukannya dikesampingkan. Meskipun sebagian mahasiswa masih memiliki sikap kritis dan kepedulian yang mendalam terhadap berbagai isu di masyarakat, namun secara umum dapat dikatakan bahwa mayoritas mahasiswa di kampuskampus lebih bersifat pragmatis dan berorientasi akademik. Bagaimana mereka memperoleh ijazah dan seterusnya mendapatkan pekerjaan yang baik. Mereka tidak begitu berminat untuk menyertai forum politik atau perbincangan tentang persoalan masyarakat di luar kampus, yang dianggap hanya membuang masa dan lebih baik menumpukan pada pelajaran (Abu Bakar, 1993:63).

Pemerintah berpendapat bahwa keterlibatan mahasiswa dalam berbagai persoalan di luar justru berbahaya dan memecah belah warga kampus. Tugas utama mereka adalah belajar dan bukan berpolitik. Dalam kaitan ini pemerintah lebih melihat mahasiswa sebagai individu yang perlu memenuhi tujuan-tujuan pembangunan. Fokus negara yang memberikan tumpuan kepada pembangunan ekonomi yang berkembang pesat menyebabkan gerakan mahasiswa tidak lagi menjadi popular. Dalam konteks ini keberhasilan pemerintah Malaysia dalam mengontrol gerakan mahasiswa, tidak saja disebabkan oleh pendekatannya yang bersifat koersif saja tetapi juga ditutupi oleh keberhasilannya dalam pembangunan berbagai bidang, terutama bidang pendidikan tinggi.

Melalui penyediaan berbagai fasilitas belajar di kampus yang memadai, skim beasiswa dan pinjaman yang disediakan, serta kemudahan-kemudahan prasarana pendidikan lainnya, secara efektif mampu meredam ketidakpuasan mahasiswa yang dapat saja beralih menjadi gerakan kolektif yang berbahaya. Pemerintah percaya bahwa kontrol yang kuat harus diimbangi dengan kompensasi material yang lebih sepadan, yang secara halus dapat menghalang mereka untuk melakukan tantangan terbuka terhadap sistem politik. Harapan ini tentu saja tidak berlebihan, mengingat potensi mereka sebagai kelompok terdidik dapat mempengaruhi perubahan sosial politik negara. Dengan cara itu pemerintah bukan hanya berhasil meredusir segala bentuk oposisi di luar negara, tetapi juga 
menghegemoni mereka secara efektif (Hilley, 2001).

Meskipun demikian bukan berarti gerakan mahasiswa telah mati. Gerakan mahasiswa tetap ada, hanya saja ia tidak sehebat seperti tahun 1970-an. Pada saatsaat tertentu gerakan mereka muncul. Kegairahan politik mahasiswa misalnya meningkat ketika Malaysia mengalami krisis ekonomi dan politik tahun 1998. Pemecatan Anwar Ibrahim dari jabatan Wakil Perdana Menteri, secara politik telah membangkitkan kesadaran mahasiswa untuk turut menyokong usaha-usaha reformasi. Sebagai akibatnya, partai pemerintah khususnya UMNO mengalami kemerosotan dalam pemilu 1999. Melalui berbagai cara, sekali lagi pemerintah berusaha keras mengontrol kecenderungan tersebut. Mahasiswa dikatakan boleh mengikuti perkembangan politik tetapi tidak boleh berpihak kepada mana-mana partai politik (Ahmad, 2003:7).

Pemerintah tidak akan pernah raguragu untuk mengenakan tindakan tegas terhadap sebarang aktivitas yang dapat mengancam stabilitas politik. Dalam kondisi demikian peluang gerakan mahasiswa semakin surut. Kini dengan kondisi pembangunan Malaysia yang semakin pesat, maka kalangan universitas justru menghadapi tantangan besar untuk menyesuaikan diri dengan berbagai perkembangan dan perubahan global yang berlangsung cepat. Sementara di satu sisi para mahasiswa semakin terbuka terhadap realitas-realitas baru yang kompleks, di sisi lain mereka berhadapan dengan pembatasan-pembatasan yang ketat. Hal ini merupakan dilema yang menjadi keprihatinan banyak pihak yang dikhawatirkan akan menumpulkan kreatifitas dan inisiatif mahasiswa serta memperlemah kesadaran sosial mereka.

Gejala ini sudah dirasakan para cendekiawan di luar maupun di di dalam kampus. Mereka khawatir situasi ini akan mempertebal rasa apatisme mahasiswa. Bahkan salah seorang cendekiawan setempat dalam sebuah artikelnya menunjukkan keprihatinan yang mendalam atas layunya aktivitas mahasiswa di luar aktivitas rutin akademik universitas, seraya mendorong kampus lebih terbuka (Baharudin Ahmad, Utusan Malaysia 15 Februari 2005). Karena itu, beberapa badan mahasiswa, seperti organisasi PersatuanPersatuan Mahasiswa serta Majelis Belia Malaysia (MBM) dan Persatuan Kebangsaan Pelajar-Pelajar Islam Malaysia (PKPIM), telah berulang kali mendesak pemerintah supaya merubah beberapa bagian dalam AUKU atau Undang-Undang Perguruan Tinggi dan Universitas 1975 yang dianggap menghalangi kebebasan mahasiswa (Abdullah, 2005:188).

Kontrol yang ketat yang dikenakan AUKU pada hakikatnya telah melahirkan 
efek psikologis yang melahirkan "budaya takut" di kalangan mahasiswa. Budaya inilah yang oleh sebagian kalangan dikhawatirkan akan mengikis keberanian dan kreatifitas mahasiswa, dan melupakan tanggung jawab sosial mereka (Abu Bakar, 1993:64). Namun sejauh ini belum ada tanda-tanda pemerintah bersedia untuk mengubah kebijakannya. Bahkan dalam pernyataan resminya yang terakhir tentang persoalan tersebut, pemerintah yang didukung oleh seluruh Majelis Perwakilan Pelajar (MPP) universitas bersikap tegas untuk tetap tidak merubah AUKU atau Undang-Undang Universitas dan Perguruan Tinggi yang ada (Utusan Malaysia, 28 Januari 2006).

Berdasarkan realitas tersebut, disadari bahwa masa depan gerakan mahasiswa di Malaysia sangat tergantung pada perkembangan politik di masa mendatang serta kebijakan-kebijakan apa yang ditempuh pemerintah. Di samping itu, gerakan mereka juga ditentukan oleh dinamika kesadaran yang berkembang di lingkungan kampus dan masyarakat itu sendiri. Dalam konteks ini, gerakan mahasiswa merupakan bagian dari gerakan masyarakat sipil secara keseluruhan.

\section{KESIMPULAN}

Perkembangan gerakan mahasiswa di Malaysia telah melalui berbagai jalan panjang. Mulai dari sebelum kemerdekaan sampai dengan awal abad 21 sekarang ini. Pasang surut gerakan mahasiswa sangat dipengaruhi oleh perkembangan politik yang ada, baik domestik maupun internasional. Dalam beberapa aspek, corak gerakan dan aktifisme mereka mengalami beberapa transformasi penting, sehingga menimbulkan gejolak dan tantangan terbuka terhadap sistem politik. Perjuangan mereka seringkali harus berhadapan dengan tatanan dan realitas politik yang lebih mengedepankan stabilitas dan keutuhan struktur kekuasaan.

Meskipun dewasa ini gerakan mahasiswa di Malaysia tidak lagi muncul secara kuat, namun pada hakikatnya golongan mahasiswa tetap merupakan kekuatan potensial yang terus dikontrol. Pemerintah berusaha kuat untuk menekan berbagai aktivitas yang dikhawatirkan memicu politisasi mahasiswa. Karena itu, aspirasi-aspirasi mahasiswa diarahkan pada dataran baru yang lebih moderat melalui penglibatan mereka dalam aktivitasaktivitas akademik dan sosial di kampus. Prestasi-prestasi pembangunan negara, nampaknya berhasil mengubah orientasi dan paradigma mayoritas mahasiswa di kampus-kampus untuk tetap berada dalam "koridor" yang sudah ditetapkan. Meskipun ada desakan beberapa pihak kepada pemerintah agar mengendurkan kontrolnya terhadap mahasiswa, namun pemerintah belum menanggapinya secara 
serius. Usaha-usaha untuk memberikan ruang yang lebih besar pada gerakan mahasiswa masih terhambat oleh sistem politik dan orientasi pembangunan yang dikembangkan pemerintah.

\section{DAFTAR RUJUKAN}

Abdullah, Saifuddin, "Kerangka Baru Gerakan Mahasiswa," dalam Abdul Razaq Ahmad (ed.), Mahasiswa Abad 21, Bangi: Fakulti Pendidikan Universiti Kebangsaan Malaysia, 2005.

Abu Bakar, Junaidi, Mahasiswa, Politik dan Undang-Undang, Kuala Lumpur: Dewan Bahasa dan Pustaka, 1993.

Abu Bakar, Mohammed, Mahasiswa Menggugat, Kuala Lumpur: Pustaka Antara, 1973.

Ahmad, Baharudin, "Apabila Universiti di Malaysia Begitu Sunyi", Utusan Malaysia, 15 Februari 2005.

Ahmad, Idris, “Agenda Politik Kepartian Lambang Kewibawaan Pimpinan Mahasiswa”, Makalah Kongres Mahasiswa USM, 10-12 April 2003.

Anwar, Zainah, Kebangkitan Islam di Malaysia, Terj. Umm Hasannain, Jakarta: LP3ES, 1990.

“AUKU 1971 Tidak Akan Dimansuh", Utusan Malaysia, 28 Januari 2006.

Bulkin, Farchan, (pnyt.), Analisa Kekuatan Politik Indonesia, Jakarta: LP3ES, 1985.
Crossley, N., Making Sense of Social Movements, Buckingham: Open University Press, 2002.

Porta, Della D., and Diani, M., Social Movements: An Introduction, Oxford: Blackwell, 1999.

Hassan, M. Zein, Diplomasi Revolusi Indonesia di Luar Negeri: Perjuangan Pemuda/Mahasiswa Indonesia di Timur Tengah, Jakarta: Bulan Bintang, 1980.

Hilley, John, Malaysia: Mahathirism, Hegemony and the New Opposition, London and New York: Zed Books, 2001.

Karim, Hassan, "The Student Movement in Malaysia 1967-74," in ImperialismNo! Democracy-Yes!: Student Movements in The Asean Region, Kuala Lumpur: Institute for Social Analysis (INSAN), 1984.

Kim, Khoo Kay, "Mahasiswa Dulu dan Kini: Satu Pandangan," dalam Abdul Razaq Ahmad (ed.), Mahasiswa Abad 21, Bangi: Fakulti Pendidikan Universiti Kebangsaan Malaysia, 2005.

Rahim, Rohani Abd., (dkk.), Hak dan Tanggungjawab Akta Universiti dan Kolej Universiti, Bangi: Universiti Kebangsaan Malaysia, 1992.

Roff, William R., "Indonesian and Malay Students in Cairo in the 1920's," Indonesia, No. 9, (April), 1970:7387.

Sang, Mok Soon, Pendidikan di Malaysia, Subang Jaya, Selangor: Kumpulan Budiman Sdn. Bhd., 2003.. 